\title{
CylE and mig as virulence genes of streptococci isolated from mastitis in cows and buffalo in Egypt
}

\author{
Rehab El-Shafei ${ }^{1}$, Azza Farag ${ }^{2}$, Rasha M. Elkenany ${ }^{3}$, Gamal Younis ${ }^{3}$ \\ ${ }^{1}$ Aga District Veterinary Hospital, Mansoura, Egypt. \\ ${ }^{2}$ Animal Health Research Institute, Dokki, Giza, Egypt. \\ ${ }^{3}$ Department of Bacteriology, Mycology, and Immunology, Faculty of Veterinary Medicine, Mansoura University, Mansoura 35516, Egypt.
}

\section{ARTICLE HISTORY}

Received: 10.10. 2020

Revised: 24.11 .2020

Accepted: 25.11 .2020

Address correspondences to Rasha M. Elkenany, PhD; Tel: +201090226696; E-mail:

dr_rashavet22@yahoo.com

\section{ABSTRACT}

\begin{abstract}
Objective: A study was carried out to investigate the prevalence of mastitis caused by Streptococcus agalactiae and Streptococcus dysgalactiae in cows and buffalo reared in households and smallholder dairy farms, and to detect their antibiotics susceptibility, and molecular investigation of some virulence genes (cylE and mig genes).
\end{abstract}

Design: Observational study.

Samples: A total of 288 milk samples were gathered from 72 mastitic animals (48 cows and 24 buffalo) from households and smallholder dairy farms in Dakahlia and Domiatte Governorates, Egypt.

Procedures: Isolation and identification of S. agalactiae and S. dysgalactiae was performed usin conventional techniques. The identified isolates were examined for antimicrobial resistance by dis diffusion assay, Minimum inhibitory concentration MIC by broth microdilution method as well a virulence genes (cylE and mig genes) by polymerase chain reaction (PCR).

Results: Forty-five (62.5\%) out of 72 animals showed the clinical signs of mastitis. Microbiological evaluation of 288 mastitis milk samples was displayed 190 (65.72\%) streptococci strains composing of $114(60 \%)$ S. agalactiae and 76 (40\%) S. dysgalactiae strains. The antibiotic susceptibility tests revealed that S. agalactiae strains was resistant to trimethoprim (100\%), followed by tetracycline and minocycline $(37.7 \%)$, whereas intermediate resistant was observed to other tested antibiotics. Moreover, S. dysgalactiae strains were highly resistant to lincomycin, tetracycline (87.52 each), followed by trimethoprim (81.6) and minocycline (75\%), while all strainswere susceptible to penicillin, amoxicillin, cephapirin, and cefquinome. Additionally, the highest MIC with the widest range ( 1 to $\geq 128$ $\mu \mathrm{g} / \mathrm{mL}$ ) was observed to trimethoprim for $S$. agalactiae and to erythromycin and lincomycin for $S$. dysgalactiae. In contrast, the lowest MIC was detected to penicillin, amoxicillin, cefquinome, and erythromycin for S. agalactiae and to penicillin, amoxicillin, cephapirin, cefquinome, and rifaximin for S. dysgalactiae. The cylE gene was displayed in $6(60 \%)$ S. agalactiae strains, whereas the mig gene was found in 4 (40\%) S. dysgalactiae strains.

Conclusion and clinical relevance: Our data highlights the importance of awareness of antibiotic resistar strains of S. agalactiae and S. dysgalactiae in various mastitic animals (cows and buffalo) in Egypt.

Keywords: Antibiotic susceptibility; Cows and buffalo; Mastitis; Streptococci, Virulence genes (cylE, mig).

\section{INTRODUCTION}

Bovine mastitis is one of the furthermost challenging infections having a global economic influence on the dairy industry, numerous bacterial genera and species able to cause mastitis extensive in the environment of dairy cows [1]. Various pathogens have been pronounced as an etiology of bovine mastitis. Based on their epidemiology, mastitis microorganisms have been categorized into two groups contagious and environmental. The main reservoir of contagious pathogens is an infected udder while a contaminated environment is the most important reservoir of pathogens producing environmental mastitis [2]. Streptococcus agalactiae (S. agalactiae), S. dysgalatiae, and
S. uberis have been stated as the furthermost three common causative agents of mastitis [3]. S. agalactiae, as well recognized as Group B Streptococcus (GBS) succeeding in the Lancefield category [4], is extremely contagious agents and usually establish in the mammary gland of cattle. $S$. agalactiae is frequently related to acute clinical and persistent subclinical mastitis [5].

There are scarce antibiotic investigation networks for animal bacterial strains meanwhile they are hard to set up, preserve, and progress. According to recent studies, the antibiotic resistance of udder pathogens is a global widespread. The local variances in resistance patterns of pathogens are predominant; even though considerable use and occasionally abuse some antibiotics remain efficient today however [6]. 
S. agalactiae has a diversity of virulence factors associated with pathogenicity. Several s. agalactiae virulence factors were identified in the mouse and rat models, main virulence factors of $S$. agalactiae comprise fibrinogen binding protein $(f n b)$, laminin-binding protein $(\mathrm{Imb})$, fibronectin-binding protein (pavA), $\beta-C$ protein (cba), capsule, C5a peptidase (scp), hyaluronate lyase $(h y / B), \alpha-C$ protein, $\beta$ - peptidase (scp), hyaluronate lyase (hy/B), $\alpha-C$ protein, $\beta$ - hemolysin/cytolysin (cyl), and CAMP factor (cfb) [7]. The $c y /$ gene codes for $\beta$-hemolysin, a toxin that played a role in tissue injury and the systemic spread of the bacteria and contributes to meningitis [8].

S. dysgalactiae has been furthermost generally pronounced as a contagious pathogen nevertheless it also acts as environmental pathogens [2] $S$. dysgalactiae subsp. dysgalactiae have been considered exclusively as animal pathogens and are commonly associated with clinical and subclinical bovine mastitis.

Though the virulence factors of $S$. dysgalactiae are not so far completely unstated, a surface-expressed M-like protein, called (mig) can bind immunoglobulin G (IgG), K2 macroglobulin (K2-M) bovine immunoglobulin A (B-IgA), and acts a title role in anti-phagocytosis by bovine neutrophils in the attendance of bovine serum [9]. M-like protein and lipoteichoic acid (LTA) were present in strains of $S$. dysgalactiae isolated from bovine intramammary gland [10].

The main aim of this study was to determine the prevalence of mastitis produced by $S$. agalactiae and $S$. dysgalactiae in cows and buffalo that were tested from households and smallholder dairy farms in Dakahlia and Domiatte Governorates, Egypt and determine their susceptibility to different antibiotics. Besides, molecular investigation to detect some virulence genes (cylE and mig genes) in streptococcal isolates ( $S$. agalactiae and $S$. dysgalactiae) by PCR was performed.

\section{MATERIALS AND METHODS}

\subsection{Sampling}

In total of 288 milk samples were gathered from 72 mastitic animals (48 cows and 24 buffalo) from households and smallholder dairy farms in Dakahlia and Domiatte Governorates, between October 2016 and July 2017. The age of affected animals ranged from 5 to 8 years and the milk yield per day ranged from 20 to 30 kilos. The udder of each animal was inspected before sample collection for the recognition of clinical signs of mastitis (inflammation, asymmetry, hotness, swelling, or any physical changes). Before sample collection for bacterial investigation, the first milk stream was rejected after that tedious teat cleaning and disinfection by $70 \%$ alcohol as recommended by the National Mastitis Council [11] was achieved. Samples were collected into sterile screw-capped McCartney bottle and immediately give in to the laboratory in an ice container for further bacteriological examination.

\subsection{Isolation and identification of Streptococcus species}

The collected milk samples were streaked onto the surface of $5 \%$ sheep blood agar and Edward's media (Oxoid) [12]. The incubation of such plates was aerobically done at $37^{\circ} \mathrm{C}$ for $24-48 \mathrm{~h}$. All isolates were conventionally identified based on the following: colony morphology, Gram's stain, catalase, oxidase reactions, and esculin hydrolysis test [13]. Additionally, suspected streptococcal colonies giving grampositive cocci with catalase and oxidase negative were biochemically identified by API 20 Strep (Biomerieux, Crappone France). Serological grouping of isolates was achieved with a commercial latex agglutination kits for the identification of streptococcal groups ( A, B, C, D, F, and G) as recommended by the manufacturer [14].

\subsection{3. Antibiotic susceptibility test}

The in vitro disk diffusion method was made as described by Bauer, Kirby [15] using Mueller-Hinton agar plates. The sensitivity of Streptococcus species to 15 chemotherapeutic agents belonged to seven classes Oxoid [14] was examined; penicillin G, amoxicillin, chloramphenicol, cloxacillin, cephalexin, cephazolin, cephapirin, cefquinome, erythromycin, lincomycin, tetracycline, minocycline, trimethoprim, rifampicin, and rifaximin. These tested antibiotics were commonly utilized for therapeutic uses in dairy Egyptian farms. The results were interpreted in accordance with Clinical Laboratory Standards [16].

\subsection{Minimum inhibitory concentration (MIC)}

MIC of 15 antibiotics against representative streptococcal species (8 S. agalactiae and 16 S. dysgalactiae strains) was determined using the broth microdilution method as outlined in Overesch, Stephan [17] The range of the concentration of the antibiotics was from 0.015 to 128 $\mathrm{ug} / \mathrm{ml}$ for which only high-level resistance was mark off. Briefly, 3-5 colonies were transported into $5 \mathrm{~mL}$ of MuellerHinton broth (MHB) (Oxoid) and incubated for 16-20 $\mathrm{h}$ at $35^{\circ} \mathrm{C}$. Subsequently, almost $0.5 \mathrm{~mL}$ of this pre-inoculum was transported to $5 \mathrm{~mL}$ of $\mathrm{MHB}$ and adjusted to a turbidity of McFarland standard 0.5 to get an inoculum with almost 1.5 $\times 10^{8} \mathrm{CFU} / \mathrm{mL}$. Next, $200 \mu \mathrm{L}$ was transferred from the inoculum to $11 \mathrm{~mL}$ of MHB. Each well was completed to 100 $\mu \mathrm{L}$ of the adjusted inoculum. To verify the inoculum density of each isolate, $10 \mu \mathrm{L}$ of the final inoculum was diluted in 10 $\mathrm{mL}$ of $0.9 \% \mathrm{NaCl}$, and $100 \mu \mathrm{L}$ of this dilution was plated onto blood agar plates. The micro-titer plates were incubated aerobically for $16-20 \mathrm{~h}$ at $35^{\circ} \mathrm{C}$ and then scored by visual examination. The breakpoints used were those recommended by the CLSI [16] for streptococci. The lowest concentration of antibiotic required to inhibit bacterial growth is considered as MIC.

\subsection{Molecular detection of Streptococcus virulence- associated genes}

Bacterial DNA extraction was achieved by QIAamp DNA mini kit (Metabion, Germany) instructions for the detection of some virulence-associated genes (cylE and mig genes) in 20 randomly representative streptococcal isolates (10 S. agalactiae and $10 \mathrm{~S}$. dysgalactiae) was performed. The used 
primer pairs (Metabion, Germany) in the PCR protocols were illustrated in Table (2). The following cycling condition was performed; one cycle initial denaturation at $94{ }^{\circ} \mathrm{C}$ for 5 min, then 35 cycles comprising of denaturation at $94{ }^{\circ} \mathrm{C}$ for $30 \mathrm{sec}$, annealing at $55^{\circ} \mathrm{C}$ for $30 \mathrm{sec}$, and extension at $72{ }^{\circ} \mathrm{C}$ for $30 \mathrm{sec}$, followed by a final extension at $72{ }^{\circ} \mathrm{C}$ for $7 \mathrm{~min}$.

\section{RESULTS}

\subsection{Prevalence of streptococcal species in mastitis milk}

In practice of evaluation of the mastitis animals, a total of 72 animals encompassing of cows (48) and buffalo (24) were tested for clinical signs of mastitis. Milk samples of 45 (62.5\%) animals were found mastitic. Among the 45 animals, 35 (72.29\%) were from cows and 10 (41.66 \%) from buffalo. Regarding quarter, among 288 examined quarters, 190 (65.72\%) quarters comprising of $147 \backslash 192$ (76.56\%) from cows and $43 \backslash 96$ (44.79\%) from buffalo were mastitic. Furthermore, microbiological assessment of samples showed $190 \backslash 288(65.72 \%)$ streptococci composing of 114 (60\%) S. agalactiae and 76 (40\%) S. dysgalactiae isolates from mastitis milk samples (Table 2 ).

Table 1. Oligonucleotide primers sequences.

$\begin{array}{llcc}\text { Target gene } & \text { Sequence } & \text { Amplified product } & \text { Reference } \\ \text { cylE } & \text { TGACATTTACAAGTGACGAAG } & 248 \mathrm{bp} & \text { Jain et al. (2012) } \\ \text { Mig } & \begin{array}{l}\text { TTGCCAGGAGGAGAATAGGA } \\ \text { CGTTTTAGTTTCGGAGCA } \\ \text { TGCCTTCAATTGAGTCTGCTG }\end{array} & 188 \mathrm{bp} & \text { Krishnaveni et al. (2014) }\end{array}$

Table 2. Prevalence of mastitis and streptococcal species in milk samples ( $n=288$ ).

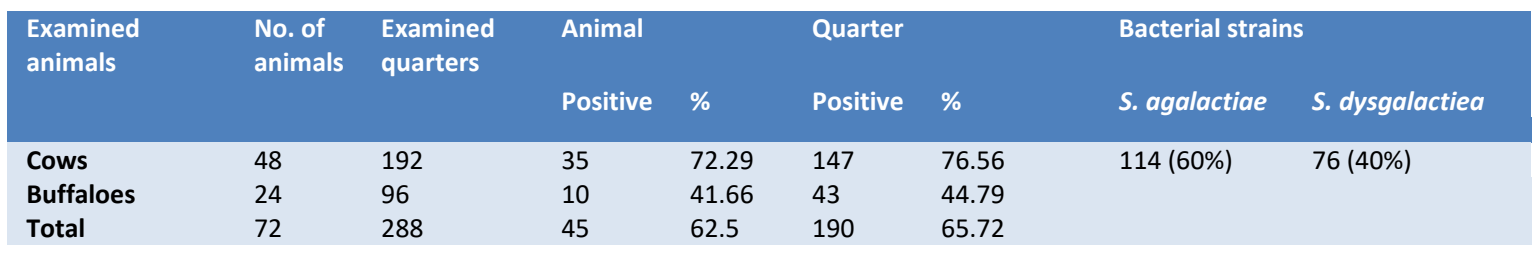

Table 3: Antibiotic susceptibility of $S$. agalactiae $(n=114)$ and $S$. dysgalactiae $(n=76)$.

\begin{tabular}{|c|c|c|c|c|c|c|c|c|c|c|c|c|}
\hline \multirow[t]{3}{*}{ Antimicrobial agent } & \multicolumn{6}{|c|}{ S. agalactiae } & \multicolumn{6}{|c|}{ S. dysgalactiae } \\
\hline & \multicolumn{2}{|c|}{ Resistant } & \multicolumn{2}{|c|}{ Sensitive } & \multicolumn{2}{|c|}{ Intermediate } & \multicolumn{2}{|c|}{ Resistant } & \multicolumn{2}{|c|}{ Sensitive } & \multicolumn{2}{|c|}{ Intermediate } \\
\hline & No & $\%$ & No & $\%$ & No & $\%$ & No & $\%$ & No & $\%$ & No & $\%$ \\
\hline Pencillin (10 IU) & 0 & 0 & 114 & 100 & 0 & 0 & 0 & 0 & 76 & 100 & 0 & 0 \\
\hline Amoxicillin |(10 ug) & 0 & 0 & 114 & 100 & 0 & 0 & 0 & 0 & 76 & 100 & 0 & 0 \\
\hline Chloramphenicol (30 ug) & 0 & 0 & 0 & 0 & 114 & 100 & 0 & 0 & 28 & 36.8 & 48 & 63.2 \\
\hline Cloxacillin (5 ug) & 28 & 24.6 & 86 & 75.4 & 0 & 0 & 0 & 0 & 33 & 43.4 & 43 & 56.6 \\
\hline Cephalexin (30 ug) & 28 & 24.6 & 0 & 0 & 86 & 75.4 & 0 & 0 & 0 & 0 & 76 & 100 \\
\hline Cefazolin (30 ug) & 0 & 0 & 28 & 24.6 & 86 & 75.4 & 0 & 0 & 0 & 0 & 76 & 100 \\
\hline Cephapirin (30 ug) & 0 & 0 & 43 & 37.7 & 71 & 62.3 & 0 & 0 & 76 & 100 & 0 & 0 \\
\hline Cefquinome (30 ug) & 0 & 0 & 71 & 62.3 & 43 & 37.7 & 0 & 0 & 76 & 100 & 0 & 0 \\
\hline Erythromycin (30 ug) & 0 & 0 & 43 & 37.7 & 71 & 62.3 & 0 & 0 & 0 & 0 & 76 & 100 \\
\hline Lincomycin (10 ug) & 0 & 0 & 0 & 0 & 114 & 100 & 65 & 87.5 & 0 & 0 & 11 & 14.5 \\
\hline Tetracycline (30 ug) & 43 & 37.7 & 0 & 0 & 71 & 62.3 & 65 & 87.5 & 0 & 0 & 11 & 14.5 \\
\hline Minocycline (30 ug) & 43 & 37.7 & 0 & 0 & 71 & 62.3 & 57 & 75 & 0 & 0 & 19 & 25 \\
\hline Trimethoprim (5 ug) & 11 & 100 & 0 & 0 & 0 & 0 & 62 & 81.6 & 0 & 0 & 14 & 18.4 \\
\hline & 4 & & & & & & & & & & & \\
\hline Rifampicin (10 ug) & 0 & 0 & 0 & 0 & 114 & 100 & 0 & 0 & 0 & 0 & 76 & 100 \\
\hline Rifaximin (10 ug) & 0 & 0 & 0 & 0 & 114 & 100 & 0 & 0 & 0 & 0 & 76 & 100 \\
\hline
\end{tabular}

\subsection{Antibiotic susceptibility results and MIC}

The results of antibiotic susceptibility tests performed on all isolates of $S$. agalactiae and $S$. dysgalactiae were illustrated in Table (3). All $S$. agalactiae strains showed absolute resistant to trimethoprim, followed by tetracycline and minocycline (37.7\%), while intermediate resistant was observed to chloramphenicol, lincomycin, rifampicin, rifaximin (100\% each), followed by cephalexin, cefazolin (75.4\% each), cephapirin, and erythromycin (62.3\% each). All S. agalactiae strains were susceptible to penicillin and amoxicillin. Moreover, $S$. dysgalactiae strains showed high resistance to lincomycin, tetracycline (87.52 each), followed by trimethoprim (81.6) and minocycline (75\%), while all strains were susceptible to penicillin, amoxicillin, cephapirin, and cefquinome.

Furthermore, Table (4) revealed that trimethoprim was the highest MIC and the widest range ( 1 to $\geq 128 \mu \mathrm{g} / \mathrm{ml}$ ) for S. agalactiae, whereas penicillin, amoxicillin, cefquinome, and erythromycin were the lowest MIC detected $(0.03$ $\mu \mathrm{g} / \mathrm{ml}$ ). Furthermore, Table (5) showed that erythromycin 
and lincomycin was the highest MIC and the widest range (1 to $\geq 128 \mu \mathrm{g} / \mathrm{ml}$ ) for $S$. dysgalactiae, whereas penicillin, amoxicillin, cephapirin, cefquinome, and rifaximin was the lowest MIC detected $(\leq 0.6-0.015 \mu \mathrm{g} / \mathrm{ml})$.
In this study and by PCR detection, the cylE gene was detected in $6(60 \%)$ strains of $S$. agalactiae (Figure 1), while the mig gene was found in $4(40 \%)$ strains of $S$. dysgalactiae (Figure 2).

\subsection{Molecular determination of streptococcal virulence- associated genes}

Table 4. Minimal inhibitory concentration (MIC) of S. agalactiae strains $(n=8)$ and ranges of antibiotic solutions performed in the study.

\begin{tabular}{|c|c|c|c|c|c|c|c|c|c|c|c|c|c|c|c|}
\hline Compound & $0.6-0.015 \leq$ & 0.03 & 0.06 & 0.12 & 0.25 & 0.5 & 1 & 2 & 4 & 8 & 16 & 32 & 64 & 128 & $\geq 128$ \\
\hline Penicillin G & 0 & 6 & 2 & - & 0 & 0 & 0 & 0 & 0 & 0 & 0 & 0 & 0 & 0 & 0 \\
\hline Amoxicillin & 0 & 1 & 5 & 2 & 0 & 0 & 0 & 0 & 0 & 0 & 0 & 0 & 0 & 0 & 0 \\
\hline Cloxacillin & 0 & 0 & 0 & 0 & 0 & 4 & 4 & 0 & 0 & 0 & 0 & 0 & 0 & 0 & 0 \\
\hline Cephalexin & 0 & 0 & 0 & 0 & 0 & 0 & 0 & 3 & 5 & 0 & 0 & 0 & 0 & 0 & 0 \\
\hline Cefazolin & 0 & 0 & 2 & 6 & 0 & 0 & 0 & - & 0 & 0 & 0 & 0 & 0 & 0 & 0 \\
\hline Cephapirin & 0 & 0 & 3 & 5 & 0 & 0 & 0 & 0 & 0 & 0 & 0 & 0 & 0 & 0 & 0 \\
\hline Cephaquinome & 0 & 5 & 3 & 0 & 0 & 0 & 0 & - & 0 & 0 & 0 & 0 & 0 & 0 & 0 \\
\hline Erythromycin & 0 & 3 & 5 & 0 & 0 & - & - & - & 0 & 0 & 0 & 0 & 0 & 0 & 0 \\
\hline Lincomycin & 0 & 0 & 0 & 0 & 8 & 0 & 0 & 0 & 0 & - & 0 & 0 & 0 & 0 & 0 \\
\hline Tetracycline & 0 & 0 & 0 & 0 & 5 & 0 & 0 & 0 & 0 & 0 & 0 & 0 & 3 & 0 & 0 \\
\hline Minocycline & 0 & 0 & 0 & 0 & 5 & 0 & 0 & 0 & - & 0 & - & 0 & 3 & 0 & 0 \\
\hline Chloramphenicol & 0 & 0 & 0 & 0 & 0 & 0 & 0 & 8 & - & 0 & - & 0 & 0 & 0 & 0 \\
\hline Trimethoprim & 0 & 0 & 0 & 0 & 0 & 0 & 0 & 0 & - & 0 & - & 0 & 0 & 0 & 8 \\
\hline Rifampicin & 0 & 0 & 2 & 5 & 1 & 0 & 0 & 0 & - & 0 & 0 & 0 & 0 & 0 & 0 \\
\hline Rifaximin & 0 & 0 & 0 & 0 & 5 & 3 & 0 & 0 & 0 & 0 & 0 & 0 & 0 & 0 & 0 \\
\hline
\end{tabular}

Table 5. Minimal inhibitory concentration (MIC) distribution for S. dysgalactiae strains ( $\mathrm{n}=16$ ) and ranges of antibiotic solutions performed in the study.

\begin{tabular}{|c|c|c|c|c|c|c|c|c|c|c|c|c|c|c|c|}
\hline Compound & $\leq 0.6-0.015$ & 0.03 & 0.06 & 0.12 & 0.25 & 0.5 & 1 & 2 & 4 & 8 & 16 & 32 & 64 & 128 & $128 \geq$ \\
\hline Penicillin & 16 & 0 & 0 & - & 0 & 0 & 0 & 0 & 0 & 0 & 0 & 0 & 0 & 0 & 0 \\
\hline Amoxicillin & 16 & 0 & 0 & 0 & 0 & 0 & 0 & 0 & 0 & 0 & 0 & 0 & 0 & 0 & 0 \\
\hline Cloxacillin & 0 & 7 & 9 & 0 & 0 & 0 & 0 & 0 & 0 & 0 & 0 & 0 & 0 & 0 & 0 \\
\hline Cephalexin & 0 & 0 & 0 & 0 & 10 & 6 & 0 & 0 & 0 & 0 & 0 & 0 & 0 & 0 & 0 \\
\hline Cefazolin & 0 & 0 & 13 & 3 & 0 & 0 & 0 & 0 & 0 & 0 & 0 & 0 & 0 & 0 & 0 \\
\hline Cephapirin & 9 & 7 & 0 & 0 & 0 & 0 & 0 & 0 & 0 & 0 & 0 & 0 & 0 & 0 & 0 \\
\hline Cephaquinome & 14 & 2 & 0 & 0 & 0 & 0 & 0 & 0 & 0 & 0 & 0 & 0 & 0 & 0 & 0 \\
\hline Erythromycin & 0 & 0 & 13 & 0 & 0 & 0 & 0 & 0 & 0 & 0 & 0 & 0 & 0 & 0 & 3 \\
\hline Lincomycin & 0 & 0 & 0 & 0 & 14 & 0 & 0 & 0 & 0 & 0 & 0 & 0 & 0 & 0 & 2 \\
\hline Tetracycline & 0 & 0 & 0 & 0 & 0 & 0 & 0 & 1 & 1 & 6 & 2 & 0 & 2 & 4 & 0 \\
\hline Minocycline & 0 & 0 & 0 & 8 & 3 & 0 & 0 & 0 & 0 & 0 & 2 & 3 & 0 & 0 & 0 \\
\hline Chloramphenicol & 0 & 0 & 0 & 0 & 0 & 0 & 0 & 10 & 6 & 0 & 0 & 0 & 0 & 0 & 0 \\
\hline Trimethoprim & 0 & 0 & 0 & 0 & 2 & 14 & 0 & 0 & 0 & 0 & 0 & 0 & 0 & 0 & 0 \\
\hline Rifampicin & 0 & 0 & 15 & 1 & 0 & 0 & 0 & 0 & 0 & 0 & 0 & 0 & 0 & 0 & 0 \\
\hline Rifaximin & 2 & 3 & 4 & 7 & 0 & 0 & 0 & 0 & 0 & 0 & 0 & 0 & 0 & 0 & 0 \\
\hline
\end{tabular}

Zero (0) indicates no isolates with an MIC at that concentration

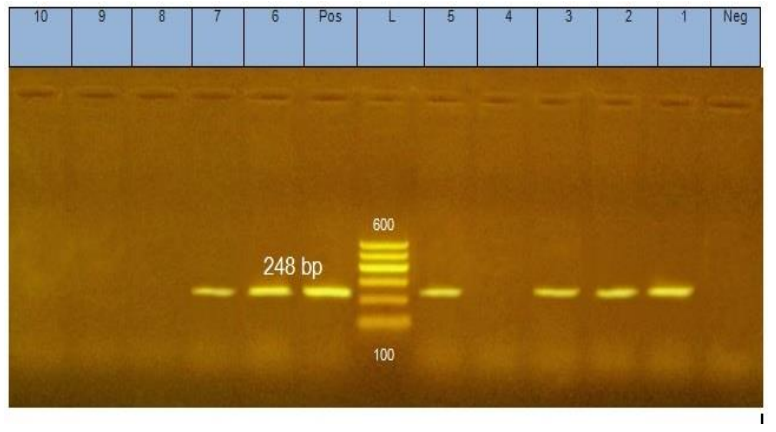

Figure 1. Agarose gel electrophoresis of $c y l E$ gene amplification (248 bp) for S. agalactiae strains isolated from milk samples. L: $100 \mathrm{bp}$ ladder. Pos: control positive. Neg: control negative. Lanes (1-3,5-7): positive samples. Lanes (4, 8-10): negative samples.

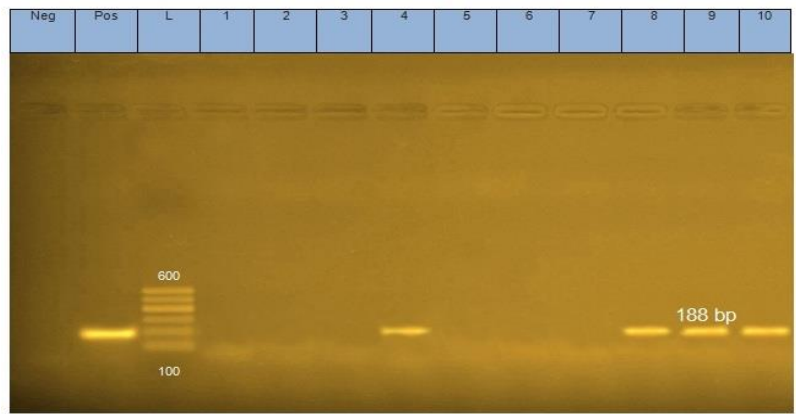

Figure 2. Agarose gel electrophoresis of $m i g$ gene amplification (188 bp) for S. dysgalactiae strains isolated from milk samples. L: 100 bp ladder. Pos: control positive. Neg: control negative. Lanes (4,8-10): positive samples. Lanes (1-3, 5-7): negative samples. 


\section{DISCUSSION}

Currently, the commercial influence of clinical and subclinical mastitis is high in the dairy industry. The economic losses arise from diminished milk production, treatment and employment costs, veterinary fees, risk of culling or death of the cow, and decreased milk quality and milk value. Additionally, low-quality milk may hold pathogens and their toxins, that may harmful for human health [18].The previous data suggested that $S$. agalactia and $S$. dysgalactiae are the main causative agents of mastitis [6]. Biochemical and molecular analysis of isolates gotten from different mastitic animals (cows and buffalo) categorically revealed S. agalactiae (60\%) and $S$. dysgalactiae (40\%). Results agree with Kia [19] and Eldesouky, Refae [20] who reported a higher prevalence of streptococci from mastitic animals (cows and buffalo) with a percentage of $75 \%$ and $38 \%$, respectively. In contrast, a lower prevalence of streptococci was shown by other investigators as Getahun, Kelay [21], Ranjan and Singh [22], Chen, Yang [23] and Jeykumar, Vinodkumar [24] with percentages of $22.8 \%, 5.7 \%, 15.5 \%$, and $16.1 \%$, respectively. The prevalence of mastitis was common in cows than buffalo because buffalo has been traditionally considered less susceptible to mastitis than cow. Buffalo have a long narrow teat canal, which may be expected to prevent the invasion of microorganism and give them higher absolute and relative resistance to pathogens [25]. The undiscriminating and ill-advised administration of antibiotics and the unreasonable treatment of bovine mastitis with diverse antibiotics were requested serious problems alike multiple drug resistance. Up to now, various kinds of antibiotics were used against the pathogens in bovine mastitis with or without identification and drug susceptibility test [26]. This study displayed high resistance of $S$. agalactiae strains to trimethoprim, tetracycline, and minocycline and intermediate resistance to the other examined antibiotics. On the other hand, the furthermost effective antibiotics against $S$. agalactiae were penicillin and amoxicillin. Therefore, $\beta$-lactams were persistence the primary choice of antibiotic recommended for the treatment of bovine mastitis. These results coincide with research performed by Erskine, Walker [27] and IKIZ, BaŞAran [18] The tetracycline resistance of Streptococcus was reported by Overesch, Stephan [17] and Tian, Zheng [28] This investigation was opposite to the results of Ebrahimi, Nikookhah [29] and Singh, Chandra [30] who displayed high resistance rates of $S$. agalactiae to amoxicillin in percentages of $76.92 \%$ and $93.03 \%$, respectively. Furthermore, $S$. dysgalactiae demonstrated high resistance to lincomycin, tetracycline, followed by trimethoprim and minocycline, while all strains were susceptible to penicillin, amoxicillin, cephapirin and cefquinome. These results were contrary to Mosaferi, Mehrabani [31] who stated that S. dysgalactiae was the greatest sensitivity to tetracycline and the least sensitivity to penicillin.

Mig protein of $S$. dysgalactiae was previously proposed to be involved in resisting phagocytosis by bovine neutrophils in the existence of bovine serum [32].
Consequently, the mig protein, an M-like protein, is represented a potential virulence factor of $S$. dysgalactiae. Also, the $c y l$ genes of $S$. agalactiae are needed to produce hemolysin [10]. Thus, some virulence-associated genes (cy/E and $m i g$ genes) were determined in streptococcal isolates (S. agalactiae and $S$. dysgalactiae) by PCR in this study. The results revealed the attendance of $c y / E$ gene in $60 \%$ of tested S. agalactiae strains and mig gene in $40 \%$ examined S. dysgalactiae strains. Jain, Tewari [33] observed $22.2 \%$ $(6 / 27)$ strains had the $c y / E$ gene while [Spellerberg, Martin [34]] detected $23 \%$ strains positive for the $c y / E$ gene.

\section{Conclusion}

The present investigation showed that a higher prevalence of $S$. agalactiae than $S$. dysgalactiae in various mastitic animals (cows and buffalo) in Egypt. Furthermore, the development of antibiotic-resistant and virulent strains of $S$. agalactiae and $S$. dysgalactiae occurred. Also, the slightly elevated MIC indicated the emergence of resistant streptococcal species. Consequently, continuous surveillance of antimicrobial-resistant mastitis pathogens is vital for the right decisions on bovine mastitis treatment.

\section{Acknowledgements}

Department of Bacteriology, Mycology and Immunology, Faculty of Veterinary Medicine, Mansoura University, Egypt, supported this study.

\section{Conflict of interest}

The authors declared no potential conflicts of interest with respect to this article.

\section{Authors' Contribution}

Gamal A. Younis designed the experiment and revised the manuscript. Azza Farag shared in the collection of samples and in carrying out the practical part. Rasha M. Elkenany shared in writing the paper and took the responsibility of correspondence to the journal. Rehab ElShafei collected milk samples and carried out the practical part. All authors approved the final version of the manuscript for publication.

\section{REFERENCES}

[1] Krishnaveni N, Isloor SK, Hegde R, Suryanarayanan VVS, Rathnma D, Veeregowda BM, et al. Rapid detection of virulence associated genes in Streptococcal isolates from bovine mastitis. Afr. J. Microbiol. Res. 2014;8:2245-54. https://doi.org/10.5897/AJMR2013.5894

[2] Surynek j, knoll a, Vrtkova I. Construction of multiplex quantitative PCR for detection of streptococcal mastitis. Mendel net. 2014;3:512-5.

[3] Amosun E, Ajuwape A, Adetosoye A. Biochemical and serological characterization of mycoplasma from bovine clinical mastitis in southwest and northern Nigeria. BAHPA. 2010;58:33-7. https://doi.org/10.4314/bahpa.v58i1.57045

[4] Lancefield RC. A SEROLOGICAL DIFFERENTIATION OF HUMAN AND OTHER GROUPS OF HEMOLYTIC STREPTOCOCCI. J. Exp. Med.. 1933;57:571-95. https://doi.org/10.1084/jem.57.4.571

[5] Arpini CM, Cardoso PG. Virulence Genes of the Streptococcus agalactiae Associated with Bovine Mastitis in Minas Gerais Livestock Herds, Brazil. Appl. Microbiol.: open access. 2016;2:2-7. https://doi.org/10.4172/2471-9315.1000119

[6] Klimienè I, Ružauskas $M$, Špakauskas V, Mockeliūnas R, Pereckienè A, Butrimaitè-Ambrozevičienè Č. Prevalence of gram positive bacteria in 
cow mastitis and their susceptibility to beta-lactam antibiotics. Vet. ir Zootech. 2011;56:65-72.

[7] Shome BR, Bhuvana M, Mitra SD, Krithiga N, Shome R, Velu D, et al. Molecular characterization of Streptococcus agalactiae and Streptococcus uberis isolates from bovine milk. Trop Anim Health Prod. 2012;44:1981-92. https://doi.org/10.1007/s11250-012-0167-4

[8] Ding $Y$, Zhao J, He X, Li M, Guan H, Zhang Z, et al. Antimicrobial resistance and virulence-related genes of Streptococcus obtained from dairy cows with mastitis in Inner Mongolia, China. Pharm. Biol.. 2016;54:162-7. https://doi.org/10.3109/13880209.2015.1025290

[9] Song X-M, Perez-Casal J, Potter AA. The Mig protein ofStreptococcus dysgalactiaeinhibits bacterial internalization into bovine mammary gland epithelial cells. FEMS Microbiol. Lett.. 2004;231:33-8. https://doi.org/10.1016/S0378-1097(03)00923-6

[10] Calvinho LF, Almeida RA, Oliver SP. Potential virulence factors of Streptococcus dysgalactiae associated with bovine mastitis. Vet. Microbiol. 1998;61:93-110. https://doi.org/10.1016/S03781135(98)00172-2

[11] National Mastitis Council. Laboratory and Field Handbook on Bovine Mastitis. 2nd Edition. USA: National Mastitis Council, Madison, Wisconsin; 1999.

[12] Quinn P, Markey BK, Carter M, Donnelly W, Leonard F. Veterinary microbiology and microbial disease: Blackwell science; 2002.

[13] Carter GR. Staining Procedures. Diagnostic Procedure in Veterinary Bacteriology and Mycology: Elsevier; 1990. p. 519-28. https://doi.org/10.1016/B978-0-12-161775-2.50042-6

[14] Oxoid $M$. Manual of culture media, ingredients and other laboratory service. In: Putturu R, Thirtham M, Eevuri T, editors.1998. p. 185-8.

[15] Bauer AW, Kirby WMM, Sherris JC, Turck M. Antibiotic Susceptibility Testing by a Standardized Single Disk Method. Am. J. Clin. Pathol. 1966;45:493-6. https://doi.org/10.1093/ajcp/45.4_ts.493

[16] CLSI. Performance standards for antimicrobial disk and dilution susceptibility tests for bacteria isolated from animals. CLSI document M31-A3. Approved Standard 3rd ed. Wayne, PA: CLSI; 2008.

[17] Overesch G, Stephan R, Perreten V. Antimicrobial susceptibility of gram-positive udder pathogens from bovine mastitis milk in Switzerland. Schweiz. Arch. 2013;155:339-50. https://doi.org/10.1024/0036-7281/a000469

[18] İKiz S, BaŞAran B, BiNgÖL EB, ÇEtiN Ö, KaŞıkÇı G, ÖZgÜR NY, et al. Presence and antibiotic susceptibility patterns of contagious mastitis agents (Staphylococcus aureus and Streptococcus agalactiae) isolated from milks of dairy cows with subclinical mastitis. Turk J Vet Anim Sci. 2013;37:569-74. https://doi.org/10.3906/vet-1302-63

[19] Kia G. Prevalence and Antibiotic Susceptibility of Streptococcus spp. in Cows with Mastitis in Germi, Iran. Anim Vet Sci 2014;2:31. https://doi.org/10.11648/j.avs.20140202.13

[20] Eldesouky I, Refae M, Elnaby H. Molecular Detection of Streptococcus Species Isolated from Cows with Mastitis. World's Vet. J.. 2016;6:193. https://doi.org/10.5455/wvj.20161085

[21] Getahun K, Kelay B, Bekana M, Lobago F. Bovine mastitis and antibiotic resistance patterns in Selalle smallholder dairy farms, central Ethiopia. $\begin{array}{lll}\text { Trop Anim Health Prod 2007;40:261-8. } & \text {. }\end{array}$ https://doi.org/10.1007/s11250-007-9090-5

[22] Ranjan R, Singh M. Study of bovine mastitis in different climatic conditions in Jharkhand, India. Vet. World. 2011:205. https://doi.org/10.5455/vetworld.2011.205-208

[23] Chen Y, Yang Z, Liu W, Chang Q, Wang L, Zhang N. Prevalence and major pathogen causes of dairy cows subclinical mastitis in Northeast China. J Anim Vet Adv 2012;11:1278-80. https://doi.org/10.3923/javaa.2012.1278.1280

[24] Jeykumar M, Vinodkumar G, Bashir B, Krovvidi S. Antibiogram of mastitis pathogens in the milk of crossbred cows in Namakkal district, Tamil Nadu. Vet. World 2013;6:354 https://doi.org/10.5455/vetworld.2013.354-356

[25] Elhaig MM, Selim A. Molecular and bacteriological investigation of subclinical mastitis caused by Staphylococcus aureus and Streptococcus agalactiae in domestic bovids from Ismailia, Egypt. Trop Anim Health Prod 2015;47:271-6. https://doi.org/10.1007/s11250-014-0715-1

[26] Ganguly S. Bacteriological Examination of Cow Milk Samples Suspected of Clinical Mastitis: A Case Study. Int. J. Pure App. 2017;5:207-9. https://doi.org/10.18782/2320-7051.2518

[27] Erskine RJ, Walker RD, Bolin CA, Bartlett PC, White DG. Trends in Antibacterial Susceptibility of Mastitis Pathogens During a Seven-Year $\begin{array}{llll}\text { Period. } & \text { J. } & \text { Dairy } & \text { Sci. }\end{array}$ https://doi.org/10.3168/jds.S0022-0302(02)74172-6

[28] Tian XY, Zheng N, Han RW, Ho H, Wang J, Wang YT, et al. Antimicrobial resistance and virulence genes of Streptococcus isolated from dairy cows with mastitis in China. Microb. Pathog. 2019;131:33-9. https://doi.org/10.1016/j.micpath.2019.03.035

[29] Ebrahimi A, Nikookhah F, Nikpour S, Majiian F, Gholami M. Isolation of Streptococci from Milk Samples of Normal, Acute and Subclinical Mastitis Cows and Determination of Their Antibiotic Susceptibility Patterns. Pak J Biol Sci 2008;11:148-50. https://doi.org/10.3923/pjbs.2008.148.150

[30] Singh K, Chandra M, Kaur G, Narang D, Gupta DK. Prevalence and Antibiotic Resistance Pattern among the Mastitis Causing Microorganisms. Open J. Vet. Med. 2018;08:54-64. https://doi.org/10.4236/ojvm.2018.84007

[31] Mosaferi S, Mehrabani RG, Khakpoor M, Mehrabani NG, Maleksabet A, Hamidi F. Prevalence of bacterial agents isolated from clinical cases of bovine mastitis in the dry period and the determination of their antibiotic sensitivity in Tabriz, Iran. J. Coast. Life Med. 2015;3:701-3. https://doi.org/10.12980/jclm.3.2015j5-88

[32] Song X-M, Perez-Casal J, Bolton A, Potter AA. Surface-Expressed Mig Protein ProtectsStreptococcus dysgalactiae against Phagocytosis by Bovine Neutrophils. Infect. Immun. 2001;69:6030-7. https://doi.org/10.1128/IAI.69.10.6030-6037.2001

[33] Jain B, Tewari A, Bhandari BB, Jhala MK. Antibiotic resistance and virulence genes in Streptococcus agalactiae isolated from cases of bovine subclinical mastitis. Vet. Arh. 2012;82:423-32.

[34] Spellerberg B, Martin S, Brandt C, LÃ $1 / 4$ tticken R. Thecylgenes ofStreptococcus agalactiaeare involved in the production of pigment. FEMS Microbiol. Lett. 2000;188:125-8. https://doi.org/10.1111/j.1574-6968.2000.tb09182.x 